\title{
GLOSA DO WYROKU WOJEWÓDZKIEGO SĄDU ADMINISTRACYJNEGO Z DNIA 28 WRZEŚNIA 2010 R., SYGN. II SA/OL 451/10
}

WYROK WOJEWÓDZKIEGO SĄDU ADMINISTRACYJNEGO

Z DNIA 28 WRZEŚNIA 2010 R., SYGN. II SA/OL 451/10

Ograniczenie prawa własności stanowiące konsekwencję ustanowienia użytku ekologicznego musi być jednoznaczne obszarowo.

Wojewódzki Sąd Administracyjny po rozpoznaniu [...] sprawy ze skargi T.S. stwierdza nieważność zaskarżonego rozporządzenia wojewody [...] w sprawie ustanowienia użytku ekologicznego [...].

* Prof. zw. dr hab., Katedra Prawa Górniczego i Ochrony Środowiska, Wydział Prawa i Administracji, Uniwersytet Śląski. 


\section{Z UZASADNIENIA}

Rozporządzeniem Nr 38 z dnia 30 lipca 2009 r., podjętym na podstawie art. 44 ust. 1 i ust. 2 ustawy z dnia 16 kwietnia 2004 r. o ochronie przyrody i ogłoszonym w Dzienniku Urzędowym [...] wojewoda ustanowił użytek ekologiczny „Z.” o powierzchni ok. 500 ha postanawiając że, zabrania się tam wskazanych tym rozporządzeniem zachowań.

Skarżący powołując się na to, że wspomniany użytek w całości zlokalizowany jest na nieruchomości stanowiącej jego własność, wezwał wojewodę do usunięcia naruszenia jego interesu prawnego poprzez uchylenie zaskarżonego rozporządzenia. Zdaniem skarżącego rozporządzenie zostało wydane w sposób urągający standardom stanowienia prawa miejscowego, bez przeprowadzenia aktualnych badań fauny i flory na tym obszarze oraz w oparciu o stare i nieaktualne badania środowiskowe. W uzasadnieniu rozporządzenia nie podano żadnych danych, nawet bardzo ogólnych, poprzestając na opisie terenu i wyliczeniu roślin i zwierząt żyjących w obrębie „Z.” Podstawą do wydania powyższego aktu był wniosek Towarzystwa A, które nie posiada żadnej dokumentacji prowadzonych obserwacji migracji ptaków, ani też nigdy nie prowadziło na terenie użytku żadnych badań, nawet polegających na liczeniu ptaków. Zwraca uwagę pośpiech z jakim podjęto rozporządzenie - 10 dni od złożenia wniosku, bowiem od dnia 1 sierpnia 2009 r. (dwa dni po wydaniu rozporządzenia) kompetencje w zakresie tworzenia użytków ekologicznych „przeszły” od wojewody do samorządu gminnego.

Wojewoda poinformował, że pełna waloryzacja ekologiczna użytku ekologicznego „Z” [...] została wykonana na potrzeby objęcia tego terenu ochroną prawną. Teren użytku był regularnie monitorowany, Towarzystwo A. prowadziło projekt „Ochrona terenów wodno-błotnych stanowiących ostoje żurawia", a jednym z zadań projektu była inwentaryzacja miejsc noclegowiskowych żurawia oraz określenie potrzeb ochrony czynnej na danym obszarze. W ubiegłych latach zostały wykonane inwentaryzacje zlotowisk żurawi, w ramach których 4/2012 prowadzono liczenia również na terenie, który został objęty 
ochroną na podstawie wspomnianego rozporządzenia. Wiedza o walorach przedmiotowego terenu jest znaczna i wystarcza do określenia jego wartości przyrodniczej. Regionalny dyrektor ochrony środowiska, działając w ramach porozumienia w sprawie powierzenia zadań należących do właściwości wojewody z zakresu ochrony przyrody, sporządzał projekty rozporządzeń wojewody dotyczących użytków ekologicznych. Po ukazaniu się projektu ustawy o zmianie niektórych ustaw w związku ze zmianami w organizacji i podziale zadań administracji w województwie, przekazującej kompetencje w zakresie ustanawiania i likwidowania użytków ekologicznych, zespołów przyrodniczo-krajobrazowych, stanowisk dokumentacyjnych oraz pomników przyrody samorządom gminnym, postanowiono wydać rozporządzenia w sprawie istniejących użytków ekologicznych, które m.in. dostosowały katalog zakazów na tych obszarach do obowiązującej ustawy o ochronie przyrody. Z uwagi na to, że wiele użytków ekologicznych nie posiadało załączników graficznych, a od momentu ich ustanowienia zmianie uległa numeracja działek gruntów, na których je powołano, stwierdzono, że w celu zgodności ze stanem faktycznym oraz dla ułatwienia sprawowania nadzoru nad nimi przez organ przejmujący kompetencję należy uzupełnić i skorygować dokumentację oraz sporządzić załączniki mapowe dla tych form ochrony przyrody.

Skarżący żądając stwierdzenia nieważności wspomnianego rozporządzenia zarzucił wydanie go bez przeprowadzenia aktualnych badań fauny i flory, w oparciu o stare i nieaktualne badania środowiskowe oraz nieokreślenie obszaru i dokładnych granic użytku ekologicznego, przez co naruszono przepis art. 44 ust. 2 ustawy o ochronie środowiska. W uzasadnieniu skargi przytoczono w całości argumentację zawartą w wezwaniu do usunięcia naruszenia interesu prawnego podnosząc również, że na tym terenie istniał wcześniej użytek ekologiczny, utworzony na podstawie ustawy z dnia 16 stycznia 1991 r. o ochronie przyrody, jednakże akty wykonawcze wydane na podstawie tej ustawy utraciły moc. Dokumenty otrzymane na wniosek o udostępnienie informacji dotyczących stanu elementów przyrodniczych środowiska na terenie użytku ekologicznego jednoznacznie wskazują, że podstawą zaskarżonego rozporządzenia nie były 
nowe, aktualne i rzetelne dane, lecz dane sprzed z kilku lat. Zdaniem skarżącego wojewoda nie przytoczył w uzasadnieniu zakwestionowanego aktu żadnych wyników badań, czy projektów, które uzasadniałyby celowość jego podjęcia, a nadto wydając zaskarżone rozporządzenie nie określił wyraźnie i dokładnie jego położenia, czym naruszył przepis art. 44 ust. 2 ustawy o ochronie środowiska. Jedynie ogólnie określono, że użytek ekologiczny położony będzie na terenie gminy „[...]”. Mapa sytuacyjna stanowiąca załącznik do rozporządzenia i mająca określać granice użytku ekologicznego, w rzeczywistości ich granic nie określa granic, jest bardzo ogólna, nie zawiera numerów działek i w związku z tym, nie da się w sposób bezsprzeczny ustalić na jakim obszarze zostaje ustanowiony użytek ekologiczny. Takie wyznaczenie powierzchni i granic użytku sprawia, iż nie jest możliwe precyzyjne wyznaczenie rzeczywistego położenia i wielkości obszaru chronionego. W rezultacie skarżący nie wie, w jaki sposób ogranicza się jego własność, chociażby w kontekście prowadzenia produkcji rolnej na gruntach, które nie wchodzą w skład użytku. Zdaniem skarżącego opis granic użytku musi być na tyle dokładny, aby nie budził żadnych wątpliwości, co do możliwości ich zlokalizowania w terenie.

Wojewoda wnosząc o oddalenie skargi wskazał, że skarżący kupując działki zlokalizowane na terenie użytku ekologicznego doskonale wiedział, jakie zakazy obowiązują na przedmiotowym terenie. Odnosząc się do kwestii dotyczących braku informacji na temat precyzyjnych granic użytku podniósł, że rozporządzenie zawiera załącznik $\mathrm{w}$ postaci mapy z zaznaczonymi granicami tej formy ochrony przyrody. Granice poprowadzone zostały po konturach działek ewidencyjnych, co umożliwia ich przełożenie na mapy ewidencyjne dostępne we właściwych miejscowo urzędach gmin i starostwach.

Wojewódzki Sąd Administracyjny zważył, co następuje:

Zgodnie z art. 42 ustawy z dnia 16 kwietnia 2004 r. o ochronie przyrody użytek ekologiczny tworzy się celem ochrony pozostałości ekosystemów mających znaczenie dla zachowania różnorodności biologicznej - naturalnych zbiorników wodnych, śródpolnych i śródleśnych oczek wodnych, kęp drzew 4/2012 i krzewów, bagien torfowisk, wydm, płatów nieużytkowanej ro- 
ślinności, starorzeczy, wychodni skalnych, skarp, kamieńców, siedlisk przyrodniczych oraz stanowisk rzadkich lub chronionych gatunków roślin, zwierząt i grzybów, ich ostoi oraz miejsc rozmnażania lub miejsc sezonowego przebywania. Z ochroną tą nieodłącznie związane są ograniczenia właścicieli gruntów w korzystaniu z nich. Dotyczy to również skarżącego; powołuje się o na to, że zaskarżone rozporządzenie ogranicza możliwość korzystania z jego gruntów i uzyskiwania środków pomocowych, w szczególności z powodu niemożliwości dokładnego ustalenia granic ustanowionego użytku ekologicznego. W tych okolicznościach należało uznać, że ma on niewątpliwie interes prawny w zaskarżeniu powyższego rozporządzenia.

Zarzut nieokreślenia obszaru i dokładnych granic użytku ekologicznego jest uzasadniony, bowiem stosownie do art. 44 ust. 2 ustawy o ochronie przyrody w brzmieniu $\mathrm{z}$ dnia wydania zaskarżonego rozporządzenia ma ono określać nazwę i położenie użytku ekologicznego. Z § 1 zaskarżonego rozporządzenia wynika, że ustanawia się użytek ekologiczny o nazwie „Z” [...] o powierzchni około 500 ha, a granice tego użytku określa mapa sytuacyjna stanowiąca załącznik do rozporządzenia. Już chociażby określenie powierzchni jako „około” świadczy o naruszeniu wspomnianego art. 44 ust. 2. Z załączonej do zaskarżonego rozporządzenia mapy, ze względu na jej skalę i sposób przedstawienia na niej granicy, nie wynika gdzie dokładnie przebiega granica użytku. Nie odpowiada rzeczywistości argumentacja wojewody, wedle którego granice można ustalić posługując się dodatkowo mapami z ewidencji gruntów, bowiem pokrywają się one z granicami działek. Z porównania mapy z rozporządzenia z mapami ewidencyjnymi wynika, że granica użytku przecina działki $\mathrm{nr},[\ldots .]$.$” , co przyznał na rozprawie pełnomocnik$ wojewody. Niewątpliwie określenie położenia użytku, w tym jego granic, ma bardzo istotne znaczenie dla właściciela gruntów na których jest on ustanowiony, bowiem rozporządzenie wkracza w jego prawa właścicielskie. Ograniczanie właścicieli gruntów w korzystaniu z nich, zgodnie z art. 22 ust. 1, art. 31 ust. 3 i art. 64 ust. 3 Konstytucji RP może nastąpić tylko w drodze ustawy i w zakresie, który nie narusza istoty prawa własności. Takie ograniczenie prawa własności przewidują przepi- 
sy ustawy o ochronie przyrody upoważniające do stanowienia użytków ekologicznych. W konsekwencji ograniczenie to musi być jednoznaczne obszarowo. Właściciel gruntu ma prawo wiedzieć, na jakiej części swojego gruntu podlega ograniczeniom, a na jakich nie. Wynika to chociażby z zagrożenia karami na wypadek niezastosowania się do ustanowionych ograniczeń. Sprecyzowanie granic użytku jest też niezbędne do uzyskania środków pomocowych. Sposobów określenia granic w aktach stanowiących prawo miejscowe jest kilka, np. w oparciu o granice ewidencyjne działek, poprzez określenie numerów działek, poprzez wskazanie punktów geodezyjnych, wreszcie po granicach naturalnych biegnących w terenie (rzeki, drogi itp.). Wojewoda żadnego z tych sposobów ustalenia granicy użytku ekologicznego nie zastosował w sposób wyczerpujący. Załączona do rozporządzenia mapa nie jest wystarczająca do ustalenia granicy użytku w terenie. Zaskarżone rozporządzenie, poprzez niedokładne określenie granicy i obszaru ustanowionego użytku ekologicznego, rażąco naruszyło art. 44 ust. 2 ustawy o ochronie przyrody w brzmieniu z dnia wydania rozporządzenia.

Uzasadniony jest także następny zarzut skargi, mianowicie wydanie rozporządzenia bez przeprowadzenia aktualnych badań fauny i flory lecz w oparciu o stare i nieaktualne badania środowiskowe. Odpowiadając na ten zarzut wojewoda dołączył szereg dokumentów, które stanowiły podstawę wydania zaskarżonego aktu (jak projekt prawnej ochrony ostoi, bez daty sporządzenia i podpisu, wniosek o udzielenie dotacji przez Fundację A., pismo Towarzystwa A do skarżącego), a na wezwanie przedstawił dodatkowo m.in. sporządzoną po dacie wydania zaskarżonego rozporządzenia waloryzację faunistyczną i inwentaryzację miejsc koncentracji [...] w okresie jesiennej migracji. Wojewoda powołał się też na badania przeprowadzone w ostatnich latach przez Towarzystwo A. i inne instytucje i osoby, nie dołączając jednak wyników tych badań. Oznacza to jednocześnie, że przed wydaniem zaskarżonego rozporządzenia wojewoda nie dysponował aktualnymi badaniami bądź inwentaryzacjami mogącymi stanowić podstawę zaskarżonego tego aktu. Ten ostatni stanowi powszechnie obowiązujący akt 4/2012 prawa miejscowego. Sąd nie jest kompetentny do oceny słusz- 
ności, racjonalności, celowości lub ekonomicznej przydatności zaskarżonego aktu. Obowiązujące przepisy prawa nie przewidują konieczności przeprowadzenia przed wydaniem takiego aktu sformalizowanego postępowania dowodowego. Nie jest to bowiem akt indywidualny i nie obowiązują przy jego wydaniu przepisy k.p.a. Nie można też czynić wojewodzie zarzutów dotyczących materiałów (opinii, ekspertyz), na jakich oparł się wydając rozporządzenie. Sąd administracyjny badając legalność takiego aktu ogranicza się do badania jego zgodności w ramach obowiązującego systemu prawa. Organ stanowiący taki akt ma swobodę w jego wydaniu. Swoboda ta nie może być jednak dowolnością. W przedmiotowej sprawie, chociażby ze względu na wyżej wskazane ograniczenia w korzystaniu z własności gruntów objętych ustanowionym użytkiem ekologicznym, wojewoda aby nie popaść w dowolność, powinien zgromadzić materiały np. inwentaryzacje, opinie, ekspertyzy itp., które są niezbędne do określenia położenia użytku i ustanowienia potrzebnego do ochrony przyrody katalogu zakazów wybranych spośród wskazanych w art. 45 ust. 1 ustawy o ochronie przyrody. Wojewoda tworząc poprzednio użytek ekologiczny „[...]”, częściowo na tym samym terenie, oparł się na szczegółowej inwentaryzacji faunistycznej, która miała stanowić także podstawę wydania zaskarżonego rozporządzenia. Po latach inwentaryzacja ta tylko w znikomym stopniu może być przydatna. Niewielką przydatność mają też inne materiały wskazane przez wojewodę, szczególnie ze względu na ich nieaktualność (badania sprzed kilku lat), a często tworzonych dla innych potrzeb (np. w postępowaniach dotyczących uzyskania pozwolenia wodnoprawnego i budowlanego). W ocenie Sądu brak aktualnych materiałów badawczych na podstawie których Wojewoda mógł wydać zaskarżony akt, uniemożliwił właściwe określenie położenia obszaru użytku oraz dokonanie właściwego doboru zakazów z art. 45 ust. 1 ustawy o ochronie przyrody. Należy zatem uznać że zaskarżone rozporządzenie zostało podjęte dowolnie, przez co również w ten sposób doszło do rażącego naruszenia przepisów art. 44 ust. 1 i 2 oraz art. 45 ust. 1 ustawy o ochronie przyrody $\mathrm{w}$ brzmieniu z dnia wydania tego rozporządzenia. 
II.

\section{G L O S A}

1. Stosownie do ustawy z dnia 16 kwietnia 2004 r. o ochronie przyrody ${ }^{1}$ (w brzmieniu obowiązującym w dacie wydania opisanego wyżej rozporządzenia) prawnymi formami jej ochrony o charakterze obszarowym i obiektowym ${ }^{2}$ (tj. odniesionymi do oznaczonych nieruchomości gruntowych, ich części bądź zespołów) są parki narodowe, rezerwaty przyrody, parki krajobrazowe, obszary chronionego krajobrazu, obszary Natura 2000, pomniki przyrody, użytki ekologiczne, stanowiska dokumentacyjne oraz zespoły przyrodniczo-krajobrazowe. Ich wspólną cechą jest to, że obejmują wyznaczone w drodze przepisu prawa $^{3}$ obszary występowania elementów przyrodniczych o unikalnych wartościach, zaś konsekwencją ustanowienia takich form ochronnych jest szczególny reżim ochronny ograniczający dotychczasowe sposoby korzystania z nieruchomości. Szczegóły rzecz jasna są niezwykle złożone i ulegają zróżnicowaniu w zależności od formy ochronnej. Istotne jest natomiast, że przesłanki uzasadniające ustanowienie tych form ochronnych są niezwykle ocenne (wręcz uznaniowe). Tytułem przykładu przesłanką utworzenia parku narodowego jest istnienie szczególnych wartości przyrodniczych, naukowych, społecznych, kulturowych i edukacyjnych danego obszaru oraz konieczność zachowania różnorodności biologicznej, zasobów, tworów i składników przyrody nieożywionej i walorów krajobrazowych, przywrócenia właściwego stanu zasobów i składników przyrody oraz odtworzenia zniekształconych siedlisk przyrodniczych, siedlisk roślin,

1 Tekst pierwotny Dz. U. Nr 92, poz. 880 ze zm.; aktualny tekst jednolity: Dz. U. 2009 Nr 151, poz. 1220 ze zm. (dalej cyt. jako „u.o.p.”).

2 Niekiedy określanymi jako ochrona indywidualna.

3 Z wyjątkiem dotyczącym parku narodowego oraz obszaru Natura 2000 4/2012 są nimi akty prawa miejscowego. 
siedlisk zwierząt lub siedlisk grzybów (art. 8 u.o.p.). Zbliżone wymagania dotyczą tworzenia rezerwatów przyrody (obszary zachowane $\mathrm{w}$ stanie naturalnym lub mało zmienionym, ekosystemy, ostoje i siedliska, twory i składniki przyrody nieożywionej, wyróżniające się szczególnymi wartościami przyrodniczymi, naukowymi, kulturowymi lub walorami krajobrazowymi, art. 13 u.o.p.), parków krajobrazowych (wartości przyrodnicze, historyczne i kulturowe oraz walory krajobrazowe w celu zachowania, popularyzacji tych wartości w warunkach zrównoważonego rozwoju, art. 16 u.o.p.), obszarów chronionego krajobrazu (wyróżniający się krajobraz o zróżnicowanych ekosystemach, wartościowe ze względu na możliwość zaspokajania potrzeb związanych z turystyką i wypoczynkiem lub pełnioną funkcją korytarzy ekologicznych), pomników przyrody (twory przyrody żywej i nieożywionej lub ich skupiska o szczególnej wartości przyrodniczej, naukowej, kulturowej, historycznej lub krajobrazowej oraz odznaczające się indywidualnymi cechami, wyróżniającymi je wśród innych tworów, okazałych rozmiarów drzewa, krzewy gatunków rodzimych lub obcych, źródła, wodospady, wywierzyska, skałki, jary, głazy narzutowe oraz jaskinie) oraz pozostałych form ochronnych.

2. Z kolei „użytkami ekologicznymi” mogły być (i mogą być nadal) „zasługujące na ochronę pozostałości ekosystemów mających znaczenie dla zachowania różnorodności biologicznej - naturalne zbiorniki wodne, śródpolne i śródleśne oczka wodne, kępy drzew i krzewów, bagna, torfowiska, wydmy, płaty nieużytkowanej roślinności, starorzecza, wychodnie skalne, skarpy, kamieńce, siedliska przyrodnicze oraz stanowiska rzadkich lub chronionych gatunków roślin, zwierząt i grzybów, ich ostoje oraz miejsca rozmnażania lub miejsca sezonowego przebywania" (art. 42 u.o.p.). Pod rządem dotychczasowego stanu prawnego utworzenie takiej formy ochrony przyrody następowało w drodze rozporządzenia wojewody bądź uchwały rady gminy, bezspornie będącymi aktami prawa miejscowego ${ }^{4}$.

4 Obecnie utworzenie takiej formy ochronnej następuje w drodze uchwały rady gminy, podjętej w uzgodnieniu $\mathrm{z}$ regionalnych dyrektorem ochrony środowiska. 
Treścią takiego aktu miało być określenie nazwy obszaru, jego położenia, sprawującego nadzór, szczególnych celów ochrony, $\mathrm{w}$ razie potrzeby ustalenia dotyczące jego czynnej ochrony oraz zakazy właściwe dla tego obiektu, obszaru lub jego części, wybrane spośród wymienionych w art. 45 ust. 1 (art. 44 ust. 2). Wspomniane zakazy odnosiły się do korzystania z nieruchomości gruntowych, kształtując sposób wykonywania prawa ich własności. Skoro uszczerbki z tego tytułu podlegają kompensacie (art. 130 i nast. Prawa ochrony środowiska5), to odpowiedź na pytanie jaka jest dokładna lokalizacja takiej formy ochronnej ma znaczenie pierwszorzędne.

3. Wszystkie opisane wyżej formy ochronne były i nadal są tworzone są w drodze aktów normatywnych, bądź to przybierających postać ustawy oraz rozporządzenia Rady Ministrów (parki narodowe), rozporządzenia ministra właściwego do spraw środowiska (obszary Natura 2000) czy też aktów prawa miejscowego (pozostałe formy ochrony obszarowej oraz obiektowej). Każdy z nich może podlegać kontroli z punktu widzenia zgodności z aktami wyższej rangi, sprawowanej bądź to przez Trybunał Konstytucyjny, bądź przez wojewódzkie sądy administracyjne. Wzorcem ten kontroli jest zgodność z wymaganiami aktów wyższej rangi, zwłaszcza zaś ustawy o ochronie przyrody. Bezspornie bowiem akty tworzące wspomniane formy ochronne mają charakter wykonawczy w stosunku do ustawy o ochrony przyrody, a przywołane wyżej przepisy tej ostatniej ${ }^{6}$ muszą być traktowane jako wytyczne dotyczące treści aktu wykonawczego w rozumieniu art. 91 ust. 1 Konstytucji. Co prawda ten ostatni przepis odnosi się wyłącznie do rozporządzeń (zwłaszcza Rady Ministrów oraz ministra właściwego do spraw środowiska) i literalnie rzecz biorąc nie ma zastosowania do aktów prawa miejscowego, tyle że odrzucenie możliwości zastosowania go do tych ostatnich może powodować, że kontrola ich zgodno-

5 Ustawa z dnia 27 kwietnia 2001 r.; w wersji obowiązującej w dacie podjęcia omawianego rozporządzenia Dz. U. Nr 62, poz. 627 ze zm.; aktualny tekst jednolity Dz. U. 2008 Nr 25, poz. 150 ze zm.

6 Określające przesłanki uzasadniające ustanowienie danej formy ochrony. 
ści z prawem stanie się iluzoryczna. Organ władzy sądowniczej oceniając zgodność aktu prawa miejscowego z prawem może zatem przede wszystkim badać, czy w sprawie zachodzą przesłanki uzasadniające utworzenie danej formy ochrony przyrody. Odrzucenie tej koncepcji może prowadzić do całkowitej uznaniowości w zakresie tworzenia form ochrony przyrody, co trafnie wytknięto w glosowanym wyroku. Inaczej mówiąc niezbędną przesłanką utworzenia którejkolwiek spośród wymienionych form ochrony przyrody jest wykazanie, że na danym obszarze występują wskazane ustawą wartości przyrodnicze. Ustawodawca nie był natomiast zainteresowany regulacją określającą sposób dokumentowania tych okoliczności oraz ich aktualizacji. Trafnie zatem WSA wytknął, że wspomniane rozporządzenie podjęte zostało bez wykazania, że na objętym nim obszarze znajdują się wartości przyrodnicze zasługujące na ochronę w drodze utworzenia użytku ekologicznego. Bezsprzecznie też organy właściwe w zakresie utworzenia wspomnianych form ochronnych muszą dysponować dowodami istnienia przesłanek uzasadniających ich utworzenie. Okoliczności te podlegają kontroli, w tym sądowoadministracyjnej ${ }^{7}$. Nie ma znaczenia, kto udokumentował istnienie wspomnianych wartości. Niedopuszczalne jest natomiast, (co trafnie wytknął sąd administracyjny), aby jedynymi dowodami istnienia wspomnianych wartości były te, które pozostają w dyspozycji organizacji społecznej.

4. Poruszony tu problem stanowi zresztą fragment znaczenie szerszego zagadnienia, jakim jest stanowienie prawa miejscowego. Pomimo iż niejednokrotnie ingeruje ono niezwykle głęboko w treść i sposób wykonywania praw podmiotowych (a przede wszystkim prawa własności nieruchomości), wiele istotnych kwestii związanych z jego powstawaniem w istocie zależy od daleko idącego uznania stanowiących je organów, a ustawodawca nie wykazuje zainteresowania regulacją określającą chociażby tryb tworzenia prawa miejscowego. Nic zatem dziwnego, że jego jakość niekiedy bywa dość niska. Brak zgeneralizowanych zasad powstawania tego prawa może nadto

7 Tak też trafnie WSA w prawomocnym wyroku z dnia 12 maja 2010 r., II S.A./Kr 1540/10. 
powodować, że dokonywanie kontroli jego zgodności z aktami wyższego rządu będzie dość trudne. Nie do rzadkości należą też sytuacje, w których akt prawa miejscowego, pomimo swojego niewątpliwie generalnego charakteru, $\mathrm{w}$ istocie nabiera charakteru indywidualnego ${ }^{8}$.

5. W przedmiotowej sprawie sąd administracyjny trafnie zakwestionował niedookreśloność przesłanek wyznaczających przebieg granic użytku ekologicznego utworzonego wspomnianym rozporządzeniem. Jest poza sporem, że konsekwencją utworzenia każdej formy ochrony przyrody są ograniczenia $\mathrm{w}$ zakresie korzystania $\mathrm{z}$ objętych nią dóbr, zwłaszcza zaś nieruchomości gruntowych. W demokratycznym państwie prawnym (art. 2 Konstytucji) zakres przestrzenny tego rodzaju ograniczeń (adresowanych do właścicieli nieruchomości) musi zostać wyznaczony w sposób jednoznaczny i nie budzący wątpliwości. Stosownie do art. 64 ust. 3 Konstytucji „własność może być ograniczona tylko w drodze ustawy i tylko w zakresie, $w$ jakim nie narusza ona istoty prawa własności". Takie ograniczenie może stanowić konsekwencję m.in. opartego na ustawie aktu niższej rangi o charakterze powszechnie obowiązującym. Nie oznacza to jednak, że takowe ograniczenia, rozumiane jako umniejszenie uprawnień właściciela nieruchomości $\mathrm{w}$ stosunku przestrzeni objętej przysługującym mu prawem, mogą mieć charakter dowolny. Przede wszystkim nie mogą one naruszać „istoty prawa własności” (art. 64 ust. 3 Konstytucji). Użyty w kontekście art. 2 oraz art. 64 Konstytucji zwrot „ograniczenie" zakłada również, że przestrzenny zasięg tego rodzaju „ograniczeń” musi być jednoznaczny. Skoro określony w ten sposób reżim prawny kształtuje sposób wykonywania prawa własności (praw od niej pochodnych) nieruchomości gruntowych, to nakaz precyzyjnego wyznaczenia granic takiej formy ochronnej w dostatecznym stopniu daje się wyinterpretować już z brzmienia art. 140 k.c. oraz art. 7 Konstytucji. Również

Czego przykładem mogą być chociażby podejmowane na podstawie art.15 ustawy z dnia 21 kwietnia 2001 r. o odpadach (Dz. U. 2010 r. Nr 185, poz. 1243 ze zm.) uchwały sejmików wojewódzkich w sprawie wyznaczenie regionalnych instalacji przekształcania odpadów. 
odpowiedź na pytanie, jaki jest dokładny przebieg granic takiej formy ochronnej ma z tego punktu widzenia pierwszorzędne znaczenie, zarówno teoretyczne jak i praktyczne. Co prawda glosowany wyrok odnosi się do historycznego stanu prawnego, tyle że sformułowane w nim tezy (pomimo zmiany właściwości organów właściwych w sprawie) w pełni znajdują zastosowanie również obecnie, a nadto z powodzeniem mogą być odniesione do pozostałych form ochrony przyrody. Problem jest zatem niezwykle aktualny i doniosły.

6. Niestety, glosowany wyrok nie odnosi się do odosobnionej sytuacji. Analiza aktów normatywnych tworzących różne formy ochrony przyrody, zwłaszcza powstające w drodze aktów prawa miejscowego, ujawnia liczne nieprawidłowości $\mathrm{w}$ tym zakresie, niezwykle podobne do tych, które zostały ujawnione w glosowanym wyroku. Przykładem może być (wydane w dotychczasowym stanie prawnym) chociażby rozporządzenie nr 135 Wojewody Warmińsko-Mazurskiego z dnia 12 listopada 2008 r. w sprawie Skarlińskiego Obszaru Chronionego Krajobra$\mathrm{zu}^{9}$. Opis przebiegu granic tej formy ochronnej zawiera załącznik nr 1. Dla określenia lokalizacji punktów załamania tych granic ośmiokrotnie użyto określenia „około"10 oraz innych zwrotów o nieoznaczonej treści (jak np. „do wschodniego brzegu lasu w pobliżu jeziora”, „omijając zwartą zabudowę wsi”, „skręca zdecydowanie ku wschodowi" itp.). Inaczej mówiąc oznacza to, że w oparciu o taki opis ustalenie dokładnej lokalizacji wspomnianego obszaru nie jest możliwe, co najprościej dostrzec na przykładzie zmiany układu urbanistycznego wspomnianej wsi (np. w wyniku likwidacji części zabudowy bądź powstania nowej). Nie sposób też ustalić, co miałby oznaczać zwrot „skręca zdecy-

Dz. Urz. Woj. Warmińsko-Mazurskiego nr 178, poz. 2617.

10 Co nie jest odosobnionym przypadkiem, bowiem w praktyce takie określenie występuje również jako jedno z kryteriów wyznaczania granic innych obszarów podlegających szczególnemu reżimowi prawnemu. Zob. np. rozporządzenie Ministra Infrastruktury z dnia 12 marca 2003 r. w sprawie ustalenia granicy portu morskiego w Dziwnowie od strony lądu, Dz. U. Nr 59, poz. 525. 
dowanie". Praktyka ta nie jest odosobniona ${ }^{11}$. Co więcej, znane są również sytuacje polegające na tym, że przebieg granic formy ochrony przyrody określa załącznik do tworzącego ją aktu (prawa miejscowego), tyle że bądź w ogóle nie podlega on promulgacji we właściwym dzienniku urzędowym, bądź ten ostatni zawiera wzmiankę, że załącznik zawierający opis przebiegu granic znajduje się do wglądu w siedzibie organu, który utworzył daną formę ochronną ${ }^{12}$. Nie ma natomiast wątpliwości, że ogłoszenie aktu normatywnego w dzienniku urzędowym jest obowiązkowe.

11 Zob. np. rozporządzenia:

- nr 5/2005 Wojewody Małopolskiego z dnia 23 maja 2005 r. w sprawie ochrony Popradzkiego Parku Krajobrazowego (Dz. Urz. Woj. Małopolskiego $\mathrm{Nr}$ 309, poz. 2238), gdzie dokonując opisu przebiegu jego granic uzytko określeń "Granica Parku bierze swój początek na granicy polsko-słowackiej w rejonie góry Szczob (937 m n.p.m.) w pobliżu źródeł Białej Wody. Dalej biegnie w kierunku zachodnim w stronę Krościenka, tnąc poprzecznie południowe skłony Radziejowej nawiązując w zasadzie do granicy rolnoleśnej 700-800 m n.p.m. przez następujące punkty orientacyjne: Sucha Góra, Góra Wysoka (759 m n.p.m.), ujście Białego Potoku, Góra Stajkowa (...),

- nr 111 Wojewody Warmińsko-Mazurskiego z dnia 3 listopada 2008 r. w sprawie Obszaru Chronionego Krajobrazu Kanału Elbląskiego (Dz. Urz. Województwa Warmińsko-Mazurskiego $\mathrm{Nr}$ 176, poz. 2579), gdzie dla określenia przebiegu granic posłużono się terminologią budzącą identyczne wątpliwości, np. wyznaczając ten przebieg „na północny-wschód do rzeki Marwickiej Młynówki, otaczając ją w kierunku południowo-wschodnim wraz $\mathrm{z}$ nadrzecznym lasem, dalej z powrotem do drogi (...pomijając las po stronie północno-wschodniej)" (załącznik nr 1).

12 Przykładem może być chociażby powołane wyżej rozporządzenie nr 5/2005 Wojewody Małopolskiego w sprawie ochrony Popradzkiego Parku Krajobrazowego. Zawiera on trzy załączniki. Załącznik nr 1 przedstawia opis przebiegu granic. Załącznik nr 2 jest mapą określającą przebieg granicy, tyle że sporządzoną w skali 1:150 000, co nie pozwala na dokładne usytuowanie wspomnianych granic w terenie. Z kolei mapa w skali 1:25 000 określająca przebieg przebieg tej granicy, stanowiąca załącznik nr 3, „dostępna jest w Wydziale Środowiska i Rolnictwa Małopolskiego Urzędu Wojewódzkiego w Krakowie - Oddziale Ochrony Przyrody, Leśnictwa i Łowiectwa oraz w siedzibie Popradzkiego Parku Krajobrazowego w Starym Sączu”. Praktyka ta nie jest odosobniona. Powstaje pytanie, czy określona w ten sposób dostępność wspomnianej mapy zachowuje swą aktualność również po utracie przez wojewodę kompetencji do tworzenia takiej formy ochronnej. W obecnym stanie prawnym park krajobrazowy powstaje bowiem w drodze uchwały sejmiku województwa. 
Tylko wówczas, gdy akt normatywny nie zawiera przepisów powszechnie obowiązujących, obowiązek jego ogłoszenia może zostać wyłączony $\mathrm{w}$ drodze ustawy ${ }^{13}$. Co prawda rozwiązanie to obowiązuje dopiero od 1 stycznia 2001 r., to jednak nie ma wątpliwości, że w poprzednim stanie prawnym obowiązek promulgacji w dzienniku urzędowym wojewody dotyczył wszystkich aktów prawa miejscowego, a ówcześnie obowiązujący stan prawny co do zasady nie dopuszczał możliwości wyłączenia (ograniczenia) obowiązku promulgacji wspomnianych aktów. W przeszłości wyjątek taki dopuszczano tylko w odniesieniu do miejscowych planów zagospodarowania przestrzennego, kiedy to promulgacji w dzienniku urzędowym podlegała sama uchwała rady gminy $\mathrm{w}$ przedmiocie przyjęcia takiego planu, podczas gdy załącznik zawierający treść planu nie podlegał promulgacji14. To ostatnie rozwiązanie było dyktowane znaczną objętością dawnych planów miejscowych oraz względami technicznymi, a zwłaszcza ówczesną techniką poligraficzną. Praktyka zna natomiast sytuacje, kiedy to w takiej sytuacji ustalenie, co w istocie było treścią takiego planu miejscowego, stawało się niezwykle utrudnione i mogło stawać się źródłem nadużyć.

7. Teoretycznie rzecz biorąc najmniej wątpliwości powinno budzić ustalanie granic obszarów objętych szczególnym reżimem ochronnym w oparciu o załączniki mapowe do aktów tworzących takie obszary. Taką technikę przyjmuje np. rozporządzenie Ministra Środowiska z dnia 12 stycznia 2011 r. w sprawie obszarów specjalnej ochrony ptaków ${ }^{15}$, stanowiących jedną z form ochrony obszarów Natura 2000. Granice wspomnianych obszarów wyznaczono na załącznikach mapowych sporządzonych w skali 1:50 000, podczas gdy grubość kreski wyznaczającej przebieg granicy wynosi około $1 \mathrm{~mm}$, co w terenie daje pas o szerokości około $50 \mathrm{~m}$. W konsekwencji nie wiad-

13 Zob. art. 2 ustawy z dnia 20 lipca 2000 r. o ogłaszaniu aktów normatywnych i niektórych innych aktów prawnych, Dz. U. Nr 2011 nr 197, poz. 1172 ze zm.

14 Zob. art. 32 ust. 1 ustawy z dnia 12 lipca 1984 r. o planowaniu przestrzennym, Dz. U. Nr 35, poz. 185 ze zm.

15 Dz. U. Nr 29, poz. 133 ze zm. 
omo, czy wspomniana granica ma przebiegać środkiem, czy też wzdłuż którejś (nie wiadomo jednak której) krawędzi wspomnianego pasa. Istotę wątpliwości najprościej dostrzec wczuwając się w sytuację właściciela nieruchomości, przez którą lub w pobliżu której przebiega tak wyznaczona granica. Odpowiedź na pytanie, gdzie dokładnie została ona zlokalizowana, jest jednocześnie odpowiedzią o treść obowiązujących wymagań ochronnych, w tym ograniczeń zachowania się jej właściciela. Jeszcze gorzej kształtuje się reżim prawny tzw. siedliskowych obszarów Natura 2000. Stan prawny w tym zakresie jest dość skomplikowany i brak miejsca by w ramach glosy przedstawiać jego szczegóły. Dość wspomnieć, że dzisiejszego dnia nie ukazało się żadne rozporządzenie ministra właściwego do spraw środowiska tworzące takie formy ochronne. Za sprawą ustawy o ochronie przyrody reżim ochronny stanowiący konsekwencję wyznaczenia obszaru Natura 2000 stosuje się odpowiednio do proponowanych obszarów mających znaczenie dla Wspólnoty, znajdujących się na liście, o której mowa w art. 27 ust. 3 pkt 1 wspomnianej ustawy. Taką listę opracowuje Generalny Dyrektor Ochrony Środowiska, a minister właściwy do spraw środowiska, po uzyskaniu zgody Rady Ministrów, przekazuje Komisji Europejskiej listę proponowanych obszarów mających znaczenie dla Wspólnoty. Rozwiązanie to urąga elementarnym standardom konstytucyjnym. W praktyce oznacza ono, że reżim ochronny obszaru siedliskowego - stosuje się odpowiednio) pomimo iż taki obszar nie został wyznaczony w prawem przewidziany sposób. Co więcej, właściciel nieruchomości objętej takim „projektowanym obszarem siedliskowym” może nie mieć świadomości opisanych wyżej działań. Informacji o tych sprawach nie ma $\mathrm{w}$ jakimkolwiek organie promulgacyjnym (dzienniku urzędowym), zaś strona internetowa, na której takie informacje może się znajdować, na szczęście nie może być traktowane jako organ promulgacyjny. Orzecznictwo sądów administracyjnych skwapliwie ucieka od tego problemu wychodząc z założenia, że projektowany reżim ochronny takich obszarów ma charakter powszechnie wiążący, czego przykładem może być chociażby orzecznictwo dotyczące tzw. Doliny Rospudy bądź in4/2012 nych przedsięwzięć, które miały być realizowane w granicach 
projektowanych obszarów siedliskowych. Brak miejsca nie pozwala na rozwinięcie problemu. Dość jednak wspomnieć, że żaden przepis Konstytucji nie dopuszcza możliwości kształtowania praw (obowiązków) obywatelskich poprzez rozwiązania, które $\mathrm{w}$ istocie stanowią dopiero projekt, $\mathrm{w}$ dodatku niejawny. Co więcej, elementem wspomnianej listy nie jest określenie granic tak projektowanych form ochronnych. Rozwinięcie szczegółów wykracza poza ramy glosy ${ }^{16}$.

8. Konsekwencją wdrożenia którejkolwiek formy ochrony przyrody odnoszącej się do nieruchomości gruntowych są najprzeróżniejsze ograniczenia zachowania się człowieka, przybierające postać zakazów bądź uzależniających niektóre takie zachowania od zgody właściwego organu administracji. Niekiedy wynikają one z mocy samej ustawy (jak to np. przyjęto $\mathrm{w}$ odniesieniu do parków narodowych, rezerwatów przyrody oraz Natury 2000), czy też wynikają z treści aktu ustanawiającego taką formę ochronną (np. w odniesieniu do parków krajobrazowych bądź obszarów chronionego krajobra$\mathrm{zu}$ ). Warto wspomnieć, że orzekając w zbliżonym stanie faktycznym, związanym z utworzeniem tzw. obszaru ograniczonego użytkowania ${ }^{17}$, NSA trafnie przyjął, że określenie w załączniku mapowym, sporządzonym w skali 1:10.000, granic obszaru ograniczonego użytkowania kreską znacznej grubości, powoduje, iż niemożliwym jest dokładne określenie miejsca położenia szeregu działek. Na brak takiej możliwości wskazuje również określenie poszczególnych odcinków granic w tekście rozporządzenia jedynie w przybliżeniu. Przepisy prawa geodezyjnego i kartograficznego ani także kodeksu cywilnego dotyczące granic nieruchomości nie zawierają regulacji mogącej uzasadniać nieprecyzyjne (dowolne, w przybliżeniu) określenie

16 Zob. A. Lipiński, Utworzenie obszaru Natura 2000 jako problem konstytucyjny, [w:] Prawo i polityka w ochronie środowiska. Studia z okazji 40-lecia pracy naukowej Jerzego Sommera, Wrocław 2006, s. 89 i nast.

17 Co prawda „obszar ograniczonego użytkowania” wyznaczany jest w celach nie związanych z ochroną przyrody, tyle że skoro konsekwencją jest powstania są ograniczenia w zakresie wykorzystywania objętych nim nieruchomości, to oczywistym jest iż jednym z kluczowych problemów staje się potrzeba precyzyjnego ustalenia przebiegu jego granic. 
ich przebiegu ${ }^{18}$. Ocena ta zasługuje na aprobatę, bowiem w przeciwnym razie należałoby się liczyć z niedopuszczalnymi próbami dookreślenia przebiegu tych granic przez nielegitymowane do tego organy i w niedopuszczalnej prawem formie. Potrzeba precyzyjnego ustalenia przebiegu wspomnianych granic znajduje bowiem swe uzasadnienie $\mathrm{w}$ wymaganiach dotyczących ochrony praw podmiotowych, zwłaszcza zaś prawa własności. Niekiedy organ tworzący daną formę ochronną wyznacza jej granice posługując się obydwoma metodami, tj. zamieszczając opis przebiegu granic oraz załącznik graficzny. Nie można natomiast wykluczyć, że każda metoda określenia przebiegu wspomnianych granic da wówczas inny rezultat, co w efekcie może prowadzić do całkowitej dowolności, przede wszystkim skutkującej daleko posuniętym stanem niepewności po stronie właściciela nieruchomości.

9. Odrębnym problemem jest próba odpowiedzi na pytanie, jakie skutki (potencjalne zakazy zachowania się) powoduje utworzenie użytku ekologicznego. Stosownie do art. 45 ust. 1 u.o.p. mogą one dotyczyć:

- niszczenia, uszkadzania lub przekształcania obiektu lub obszaru ${ }^{19}$,

- wykonywania prac ziemnych trwale zniekształcających rzeźbę terenu, z wyjątkiem prac związanych z zabezpieczeniem przeciwsztormowym lub przeciwpowodziowym albo budową, odbudową, utrzymywaniem, remontem lub naprawą urządzeń wodnych,

- uszkadzania i zanieczyszczania gleby,

18 Wyrok z dnia 4 listopada 2004 r., OSK 1151/04 z glosą (apr.). A. Miler, Orzecznictwo Sądów Polskich, 2005 nr 11, poz. 127.

19 Zakaz uszkadzania lub przekształcania obszaru oraz wykonywania prac trwale zniekształcających rzeźbę terenu nie może być utożsamiane z zakazem wykonywania prac ziemnych związanych z realizacją obiektu budowlanego. O uszkadzaniu lub przekształcaniu obszaru bądź o zniekształcaniu terenu można mówić w przypadku takich prac jak: niwelacja wzgórza, wykopanie stawu, zmiana biegu rzeki, wycięcie lasu. Nie można natomiast kwalifikować jako uszkodzenia lub przekształcenia obszaru oraz zniekształcenia terenu z prac służących do realizacji obiektu budowlanego, takich jak wykopy pod fundamenty (wyrok WSA z dnia 29 sierpnia 2008 r., sygn. akt. IV SA/Wa 4/2012 952/08, LEX 517964 
- dokonywania zmian stosunków wodnych, jeżeli zmiany te nie służą ochronie przyrody albo racjonalnej gospodarce rolnej, leśnej, wodnej lub rybackiej,

- likwidowania, zasypywania i przekształcania naturalnych zbiorników wodnych, starorzeczy oraz obszarów wodno-błotnych,

- wylewania gnojowicy, z wyjątkiem nawożenia użytkowanych gruntów rolnych,

- zmiany sposobu użytkowania ziemi,

- wydobywania do celów gospodarczych skał, w tym torfu, oraz skamieniałości, w tym kopalnych szczątków roślin i zwierząt, a także minerałów i bursztynu,

- umyślnego zabijania dziko występujących zwierząt, niszczenia nor, legowisk zwierzęcych oraz tarlisk i złożonej ikry, z wyjątkiem amatorskiego połowu ryb oraz wykonywania czynności związanych z racjonalną gospodarką rolną, leśną, rybacką i łowiecką,

- zbioru, niszczenia, uszkadzania roślin i grzybów na obszarach użytków ekologicznych, utworzonych w celu ochrony stanowisk, siedlisk lub ostoi roślin i grzybów chronionych,

- umieszczania tablic reklamowych.

Nie dotyczy to:

- prac wykonywanych na potrzeby ochrony przyrody po uzgodnieniu $\mathrm{z}$ organem ustanawiającym daną formę ochrony przyrody,

- realizacji inwestycji celu publicznego po uzgodnieniu $\mathrm{z}$ organem ustanawiającym daną formę ochrony przyrody,

- zadań z zakresu obronności kraju w przypadku zagrożenia bezpieczeństwa państwa,

- likwidowania nagłych zagrożeń bezpieczeństwa powszechnego i prowadzenia akcji ratowniczych.

10. Warto zwrócić uwagą na niesłychaną ocenność przedstawionych wyżej kryteriów, w tym na pozbawiony dostatecznej precyzji (wręcz niechlujny) aparat pojęciowy. Bezspornie jednak wykaz tych ograniczeń ma charakter zamknięty i brak podstaw by organ tworzący daną formę ochronną mógł go w jakikolwiek 
sposób poszerzyć ${ }^{20}$. Powstaje na przykład pytanie, jak rozumieć „uzgodnienie” danych czynności z organem ustanawiającym daną formę ochrony przyrody. Przede wszystkim nie jest dostatecznie jasna jego forma prawna, a zwłaszcza czy miałaby ona być decyzją organu ustanawiającego daną formę ochronną, czy być oznacza ono tylko nakaz współdziałania tego organu w procesie podejmowania przez inny organ decyzji zezwalających na przedstawione wyżej działania. Problem staje się bezprzedmiotowy w sytuacji, gdy przepis szczególny, np. odnoszący się do procesu inwestycyjnego, zawiera wyraźną regulację odnoszącą się do działań podejmowanych na terenie objętym taką ochroną. W istocie sytuacje te będą jednak należeć do rzadkości ${ }^{21}$.

20 Tak trafnie NSA w wyroku z dnia 13 kwietnia 2010 r., II OSK 169/09, LEX 597346. Niejasne stanowisko w tej mierze zajmuje K. Gruszecki, który komentując art. 45 u.o.p. przyjmuje, że „organ administracji wprowadzający konkretną formę ochrony nie ma żadnej możliwości dokonywania modyfikacji w tym zakresie". O ile ocena ta ma oznaczać, że organ tworzący wspomniane formy ochrony nie może poszerzyć katalogu ograniczeń przewidzianych w cyt. przepisie, należy się z nią zgodzić. O ile jednak miałaby ona oznaczać, że wspomniane ograniczenia ex lege dotyczą wszelkich form ochronnych wymienionych w tym przepisie, należy ją zdecydowanie odrzucić, za czym przemawia chociażby sformułowanie art. 44 ust. 2 u.o.p., który zdecydowanie przesądza, że akty tworzące wymienione w tym przepisie formy ochronne jest określa „zakazy właściwe dla tego obiektu, obszaru lub jego części, wybrane spośród zakazów wymienionych w art. 45 ust. 1" (Ustawa o ochronie przyrody. Komentarz, Warszawa 2010, s. 216 i nast.). Trafnie też W. Radecki przyjmuje, że „organ kreujący daną formę ochrony wprowadza odpowiednie zakazy, korzystając z wzorcowych wykazów zamieszczonych w art. (...) art. 45 ust. 1" (Quady na obszarach przyrodniczo cennych - uwagi z zakresu prawa karnego na tle porównawczym (Polska, Czechy, Słowacja), Prokuratura i Prawo 2010 nr 1-2, s. 223 i nast.).

21 Jak np. art. 53 ust. 4 pkt 8 ustawy z dnia 27 marca 2003 r. o planowaniu i zagospodarowaniu przestrzennym (Dz. U. 2012, poz. 647), wedle którego decyzje w sprawie lokalizacji inwestycji celu publicznego odnoszące się do terenów objętych innymi formami ochrony przyrody, niż parki narodowe (ich otuliny), wymagają uzgodnienia $\mathrm{z}$ regionalnym dyrektorem ochrony środowiska. Niejasne stanowisko zajmuje w tej mierze K. Gruszecki, który w komentarzu do art. 45 u.o.p., zależnie od okoliczności, zdaje się dopuszczać zarówno współdziałanie $\mathrm{z}$ organem ustanawiającym daną formę ochronną (art. 106 k.p.a.), jak i działanie tego organu w drodze decyzji. Problem jednak w tym, że konstrukcja art. 45 ust. 2 u.o.p. dostosowana jest do sytuacji, w której wspomniane formy były tworzone przez organ monokratyczny, jakim jest 
11. W sumie ocena wyrażona $\mathrm{w}$ glosowanym wyroku zasługuje na aprobatę. Co prawda stan prawny, na podstawie które orzekał sąd administracyjny uległ zmianie, tyle że nie wpływa to na istotę rozstrzygnięcia. Mnogość form ochrony przyrody, których ustanowienie pociąga za sobą ograniczenia zachowania się człowieka pozwala natomiast na sformułowanie przypuszczenia, że problematyka ta coraz to częściej będzie przedmiotem badania przez sądy administracyjne. Z uzasadnienia glosowanego wyroku wynika natomiast, że zarówno skarżący, jak i organ administracji powoływali się na „art. 44 ustawy o ochronie środowiska". Powstaje natomiast wątpliwość, czy przepis ten został przywołany w prawidłowy sposób. Przede wszystkim w Polsce nie ma i nigdy nie było „ustawy o ochronie środowiska". Z kolei art. 44 ustawa z dnia 27 kwietnia 2001 r. - Prawo ochrony środowiska nie obowiązywał już w dacie podjęcia zaskarżonego rozporządzenia ${ }^{22}$. Okoliczności sprawy uzasadniają natomiast ocenę, że wspomniane przywołanie zapewne odnosi się do „ustawy o ochronie przyrody ${ }^{23}$ ”, tyle że z nieznanych powodów nazwanej „ustawą o ochronie środowiska”.

wojewoda. Od 1 sierpnia 2009 r. wspomniane formy tworzone są natomiast w drodze uchwały rady gminy. Brak miejsca nie pozwala na rozwinięcie szczegółów.

22 Poprzednio odnosił się do tzw. strategicznych ocen oddziaływania na środowisko, co nie miało nic wspólnego z tworzeniem użytków ekologicznych.

23 Której art. 44 dotyczy m.in. tworzenia użytków ekologicznych. 